\title{
Detection of antimicrobial resistance genes of carbapenem-resistant Enterobacteriaceae in Escherichia coli isolated from the water supply of smallholder dairy farms in Saraburi and Maha Sarakham, Thailand
}

\author{
Natapol Pumipuntu ${ }^{1}$ and Sangkom Pumipuntu ${ }^{2}$
}

1. One Health Research Unit, Faculty of Veterinary Sciences, Mahasarakham University, Maha Sarakham 44000, Thailand; 2. Department of Educational Technology and Communications, Faculty of Education, Mahasarakham University, Maha Sarakham 44000, Thailand.

Corresponding author: Natapol Pumipuntu, e-mail: natapol.p@msu.ac.th

Co-author: SP: pumipuntu@gmail.com

Received: 18-08-2019, Accepted: 11-12-2019, Published online: 12-01-2020

doi: www.doi.org/10.14202/IJOH.2020.1-5 How to cite this article: Pumipuntu N, Pumipuntu S (2020) Detection of antimicrobial resistance genes of carbapenem-resistant Enterobacteriaceae in Escherichia coli isolated from the water supply of smallholder dairy farms in Saraburi and Maha Sarakham, Thailand, Int J One Health, 6(1):1-5.

\begin{abstract}
Background and Aim: The problem of antimicrobial resistance of bacteria in both humans and animals is an important public health concern globally, which is likely to increase, including in Thailand, where carbapenem-resistant Enterobacteriaceae (CRE), such as Escherichia coli, are of particular concern. They are pathogens found in the gastrointestinal tract of humans and other animals as well as in the environment. They may cause opportunistic infection and are often resistant to antibiotics in various fields especially in animal husbandry, such as pets or livestock farms. This study aimed to investigate the occurrence of carbapenem-resistant E. coli from water samples of smallholder dairy farms in Saraburi and Maha Sarakham, Thailand.

Materials and Methods: Sixty-four water samples were collected from 32 dairy farms in Kaeng Khoi district, Muak Lek district, and Wang Muang district of Saraburi Province, and Kantharawichai district and Mueang district of Maha Sarakham Province, Thailand. All samples were cultured and isolated for E. coli by biochemical tests. All E. coli isolates were tested for drug susceptibility using imipenem, meropenem, and drug resistance genes of carbapenemases such as $b l a_{\mathrm{NDM}}, b l a_{\mathrm{IMP}}$, and $b l a_{\mathrm{OXA} 48}$ of drug-resistant $E$. coli isolates detected by polymerase chain reaction (PCR) technique.

Results: A total of 182 E. coli isolates were found (140 and 42 isolates from Saraburi and Maha Sarakham, respectively). Drug sensitivity tests found that two isolates of $E$. coli from water in Kaeng Khoi were resistant to imipenem; therefore, the incidence of $E$. coli resistance to carbapenem was $1.43 \%$ of Saraburi Province. On the other hand, there was no incidence of drug-resistant $E$. coli in Maha Sarakham. In addition, the detection of the drug-resistant gene of $E$. coli in both isolates by PCR showed the expression of bla ${ }_{\mathrm{NDM}}$.
\end{abstract}

Conclusion: This study reports $E$. coli resistance to antimicrobial drugs on livestock farms. It can be considered to be the first report of E. coli CRE detection in a dairy farm at Saraburi, which should be the subject of further extended study.

Keywords: antimicrobial resistance, carbapenem-resistant Enterobacteriaceae, dairy farm, Escherichia coli, water.

\section{Introduction}

Escherichia coli is known as a common facultative anaerobic bacteria, which inhabits the gastrointestinal tract of animals and humans as a normal element of the bacterial flora [1]. However, it is responsible for many diseases such as diarrhea, food poisoning, cholecystitis, bacteremia, hemorrhagic colitis, cholangitis, and pneumonia in both humans and animals [2]. E. coli is also generally found in a wide range of livestock, especially in dairy cattle. It was found to frequently infect mammary glands of cows, where it is a leading cause of clinical and subclinical mastitis [3].

Copyright: Pumipuntu and Pumipuntu. This article is an open access article distributed under the terms of the Creative Commons Attribution 4.0 International License (http://creativecommons. org/licenses/ by/4.0/), which permits unrestricted use, distribution, and reproduction in any medium, provided you give appropriate credit to the original author(s) and the source, provide a link to the Creative Commons license, and indicate if changes were made. The Creative Commons Public Domain Dedication waiver (http:// creativecommons.org/ publicdomain/zero/1.0/) applies to the data made available in this article, unless otherwise stated.
$E$. coli can survive in open environments. It is found in soil, manure, feces, contaminated vegetables, contaminated seeds, and various sources of water including irrigation water, tap water, rainwater, well water, and bottled water [4]. In addition, E. coli has been isolated from farm animals and especially from the water supply in dairy farms [5].

In Thailand, antimicrobial drugs are often used for the treatment of an infected animal. Moreover, antibiotics are often used improperly for growth promotion and prophylaxis of livestock animal including dairy cows. This can lead to the emergence of bacteria resistant to those antimicrobial drugs thereby making the treatment of those bacterial infections more difficult and laborious [5]. At the present time, antimicrobial resistance of bacteria is a global problem and antimicrobial resistance of $E$. coli has been reported worldwide [6]. The prevalence of E. coli resistance to antimicrobial drugs has been increased by the emergence of the first-line antimicrobial agents such as extended-spectrum $\beta$-lactamases and the spreading of carbapenem-resistant Enterobacteriaceae (CRE), 
which have a high level of antimicrobial resistance and are more difficult to treat [7]. As E. coli can constitute and pass some drug resistance genes for its pathogenesis and ability to resist the antimicrobial drug, their level of resistance might be considered as a good indicator for studying the emergence and occurrence of antimicrobial drug resistance of E. coli [6].

There are a few studies of antimicrobial resistance and drug resistance genes in dairy cattle in Thailand. In addition, the information concerning antimicrobial resistance of $E$. coli from dairy farms, especially from water sources is very limited, although the water supply can be a reservoir of antimicrobial resistance $E$. coli to which humans and animals are exposed on the farms. This work looked for antimicrobial resistance of $E$. coli as the CRE, which was isolated from water sources for dairy cattle in dairy farms. We also detected the drug resistance genes of CRE as $b l a_{\mathrm{NDM}}$, $b l a_{\mathrm{IMP}}$, and $b l a_{\text {OXA48 }}$. The dairy farms studied were in Kaeng Khoi, Muak Lek, and Wang Muang districts of Saraburi Province, and in Kantharawichai and Mueang district of Maha Sarakham Province, Thailand.

\section{Materials and Methods}

\section{Ethical approval}

There is no need of ethical approval for this study. However, all procedures in this study, including sample collection, did not harm animals or humans.

\section{Location of study and sample collection}

A total of 64 water samples were collected from 32 smallholder dairy farms in two provinces of Thailand where livestock farming is the main source of general income of the community, i.e., eight farms from Maha Sarakham Province (Muang and Kantharawichai) and 24 farms from Saraburi Province (Kaeng Khoi, Muak Lek, and Wang Muang) in Northeast and Central of Thailand, respectively (Figure-1). All of 64 water samples from the drinking water supply of dairy cattle were collected into $500 \mathrm{ml}$ sterilized bottles using an aseptic technique. The water samples were stored at $4^{\circ} \mathrm{C}$ and transported within $24 \mathrm{~h}$ for the experiment at the One Health Research Unit laboratory at Faculty of Veterinary Sciences, Mahasarakham University and Microbiology laboratory at the Faculty of Tropical Medicine, Mahidol University.

\section{Bacterial isolation and identification}

All water samples were centrifuged at $6000 \mathrm{rpm}$ for $10 \mathrm{~min}$, and the precipitants were subjected and spread on MacConkey agar (Oxoid, UK). Bacterial colonies suspected to be $E$. coli, which showed lactose-fermenting colonies (pink colonies color), were isolated to Gram staining and standard biochemical tests, including lysine decarboxylase, triple sugar iron agar, indole production tests, ornithine decarboxylase/ deaminase, and motility.

\section{Antimicrobial susceptibility tests for CRE}

All E. coli isolates were subjected to antimicrobial susceptibility tests following the Clinical and

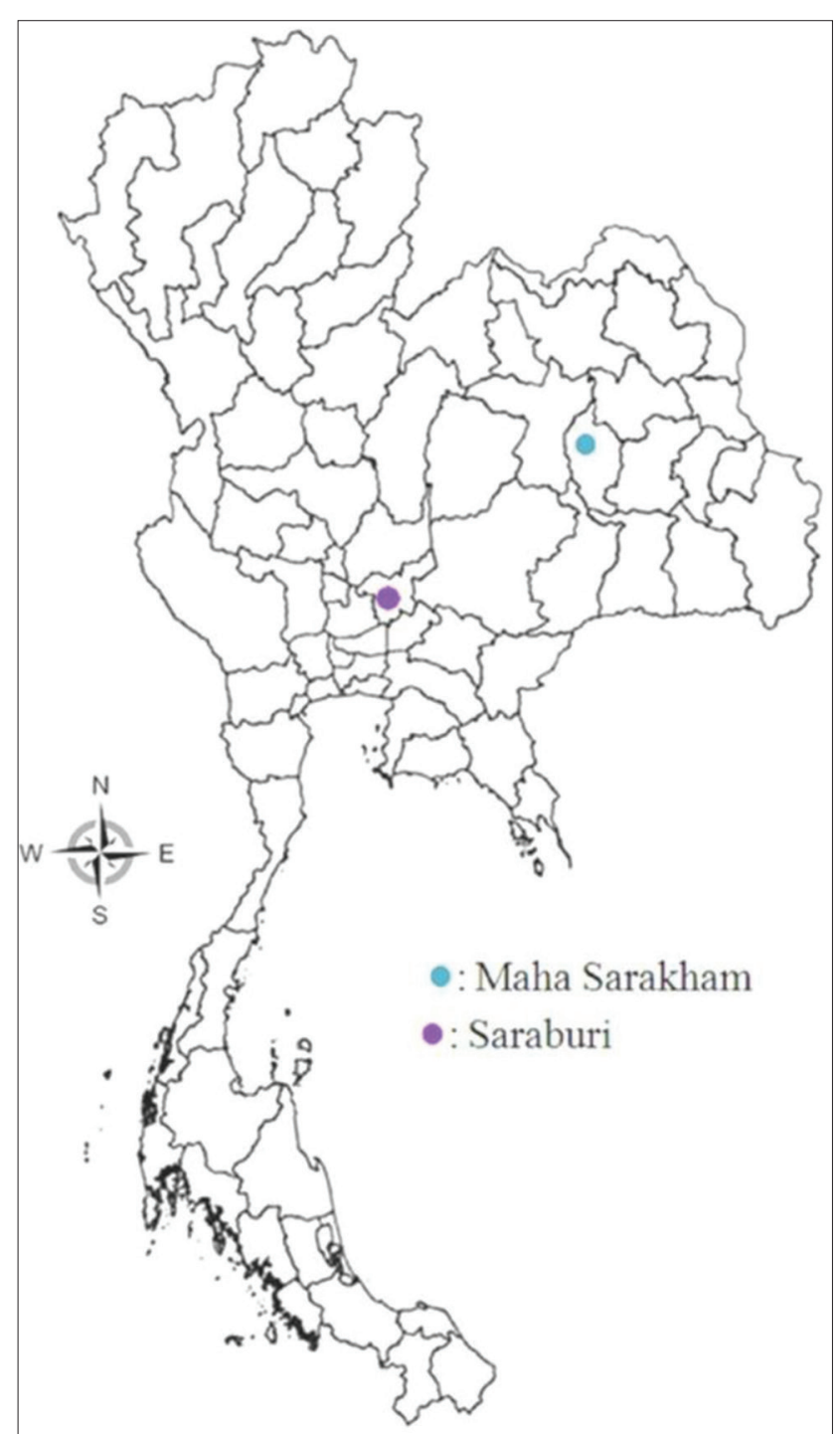

Figure-1: Study areas, the color points indicated the areas of sample collection.

Laboratory Standards Institute (CLSI) guidelines (CLSI, 2018). Antimicrobial disks were used to determine the carbapenem-resistant E. coli in the experiment, including $10 \mu \mathrm{g}$ imipenem $(\leq 19 \mathrm{~mm})$ and $10 \mu \mathrm{g}$ meropenem ( $\leq 19 \mathrm{~mm})$ (Oxoid, UK). E. coli strain ATCC 25922 was used as a sensitivity control in the experiment.

\section{Drug resistance genes detection by polymerase chain reaction (PCR)}

All E. coli isolates from both water samples were determined using representative of CRE drug resistance genes, and the isolates that showed resistance to antimicrobial drugs as imipenem and meropenem were selected and subjected to PCR to investigate their CRE drug resistance genes to confirm at the molecular level that they were CRE. The bacteria were cultured in $5 \mathrm{ml}$ of tryptic soy broth (Oxoid, UK) and incubated 18-20 $\mathrm{h}$. After that, they were harvested and centrifuged for $5 \mathrm{~min}$ at $6000 \mathrm{rpm}$. The pellet was resuspended with $700 \mu \mathrm{l}$ of sterile distilled water, boiled for $15 \mathrm{~min}$, centrifuged at $6000 \mathrm{rpm}$ for $15 \mathrm{~min}$, and then the supernatant was assembled for procedure as a 
DNA template for PCR amplification. Drug resistance gene primers, gene sequences, target gene amplicon size, condition of annealing temperature, and E. coli positive control strains which were used in PCR are presented in Table-1 [8].

\section{Statistical analysis}

The data were analyzed as a descriptive analysis using the generalized linear model of Statistical Package for the Social Sciences (SPSS) Version 16 (IBM, NY, USA).

\section{Results}

\section{E. coli isolation and CRE antimicrobial resistance}

A total of $182 \mathrm{E}$. coli isolates (140 and 42 from Saraburi and Maha Sarakham, respectively) were found in 64 water samples obtained from drinking water containers of dairy cattle on 32 dairy farms. All $182 \mathrm{E}$. coli isolates were tested from drug resistance with imipenem and meropenem susceptibility tests using the Kirby-Bauer disk diffusion method. Only two isolates (from a dairy farm of Saraburi Province) showed resistance to imipenem (occurrence rate at $1.43 \%$ of total E. coli from Saraburi). All E. coli isolates were susceptible to meropenem.

\section{Drug resistance genes detection}

PCR methods were used to detect CRE drug resistance genes $\left(b l a_{\mathrm{NDM}}, b l a_{\mathrm{IMP}}\right.$, and $\left.b l a_{\mathrm{OXA} 48}\right)$ in the two $E$. coli isolates with imipenem resistance. Three drug-susceptible $E$. coli isolates which had been collected previously from Maha Sarakham Province were also included in this analysis. Among the E. coli isolates, two with resistance to imipenem showed positive results for only bla ${ }_{\mathrm{NDM}}$ gene detection by the PCR (Figure-2) while the other genes, $b l a_{\mathrm{IMP}}$, and bla ${ }_{\mathrm{OXA} 48}$, both showed a negative result. Furthermore, the three susceptible $E$. coli isolates showed negative results to all three drug resistance genes tested.

\section{Discussion}

E. coli is recognized to be the most widespread Gram-negative bacteria that can cause diseases to both humans and animals and also exhibits antimicrobial resistance [9]. However, pathogenic E. coli in the environment has often been ignored and not much weight has been attached to preventative measures. Many studies have reported the occurrence of $E$. coli among livestock, especially in bovine mastitis cases from dairy farms in many areas of the world, predominantly in developing countries including Uruguay, Brazil, Ethiopia, Mexico, and China [10-14]. This research revealed by conventional methods, the presence of $E$. coli in environmental sources in dairy farms. The occurrence of $E$. coli in water sources in dairy farms could lead to many infections of dairy cows, including intra-mammary gland [15].

The results promote the realization and concern about $E$. coli dispersal to nearby areas through contaminated water from the farms. Besides dispersal, farmers and agricultural workers should be aware as they can be a reservoir of pathogenic bacteria. Interestingly, this study showed important information about $E$. coli becoming resistant to carbapenem antimicrobial drugs. This is the first report of the detection of carbapenem-resistant E. coli on dairy farms in Thailand, where there is a need for more concern about the usage of antimicrobial drugs. This result also implied the potential distribution of carbapenem-resistant $E$. coli within the dairy herds as well as may be infected to human and becoming the circulation of antimicrobial-resistant $E$. coli which affecting among human, animal, and environmental health that called "One Health" [16-20], as shown in Figure-3. These findings suggest that a cautious and thoughtful approach should be adopted with antimicrobial drug usage in dairy farms, especially in Saraburi Province.

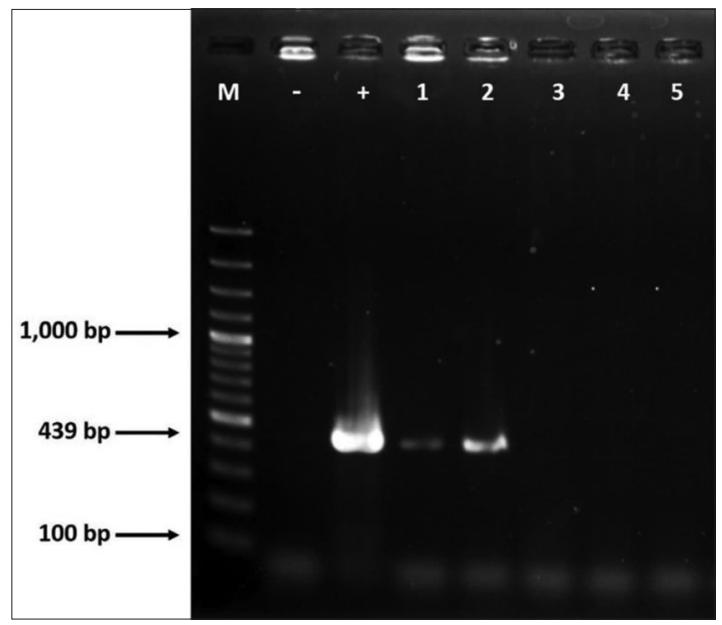

Figure-2: Gel electrophoresis detected bla ${ }_{\text {mpM }}$ gene. $\mathrm{M}=$ Ladder or marker, $-=$ Negative control (Escherichia coli ATCC 25922), +=Positive control (laboratory reference), $1=E$. coli isolate No. W $11.2 \mathrm{~A}, 2=E$. coli isolate No. W 17.1 C, 3=E. coli isolate No. W $29.1 \mathrm{~A}, 4=E$. coli isolate No. W 32.2 A, $5=E$. coli isolate No. W 26.5 B.

Table-1: The sequences, amplicon size, and annealing temperature of polymerase chain reaction primers using amplify drug resistance genes of Escherichia coli [8].

\begin{tabular}{|c|c|c|c|}
\hline Genes & Sequences & Amplicon size (bp) & $\mathrm{TM}$ in ${ }^{\circ} \mathrm{C}$ \\
\hline bla $_{\mathrm{NDM}}$ & $\begin{array}{l}\text { F: TAAAATACCTTGAGCGGGC } \\
\text { R: AAATGGAAACTGGCGACC }\end{array}$ & 439 & 52 \\
\hline$b / a_{\mathrm{IMP}}$ & $\begin{array}{l}\text { F: GAGTGGCTTAATTCTCRATC } \\
\text { R: CCAAACYACTASGTTATCT }\end{array}$ & 183 & 56 \\
\hline$b a_{\text {OXA48 }}$ & $\begin{array}{l}\text { F: GTGGTTGCTTCTCTITITCT } \\
\text { R: АTTTCTGACCGCATTTCCAT }\end{array}$ & 736 & 58 \\
\hline
\end{tabular}




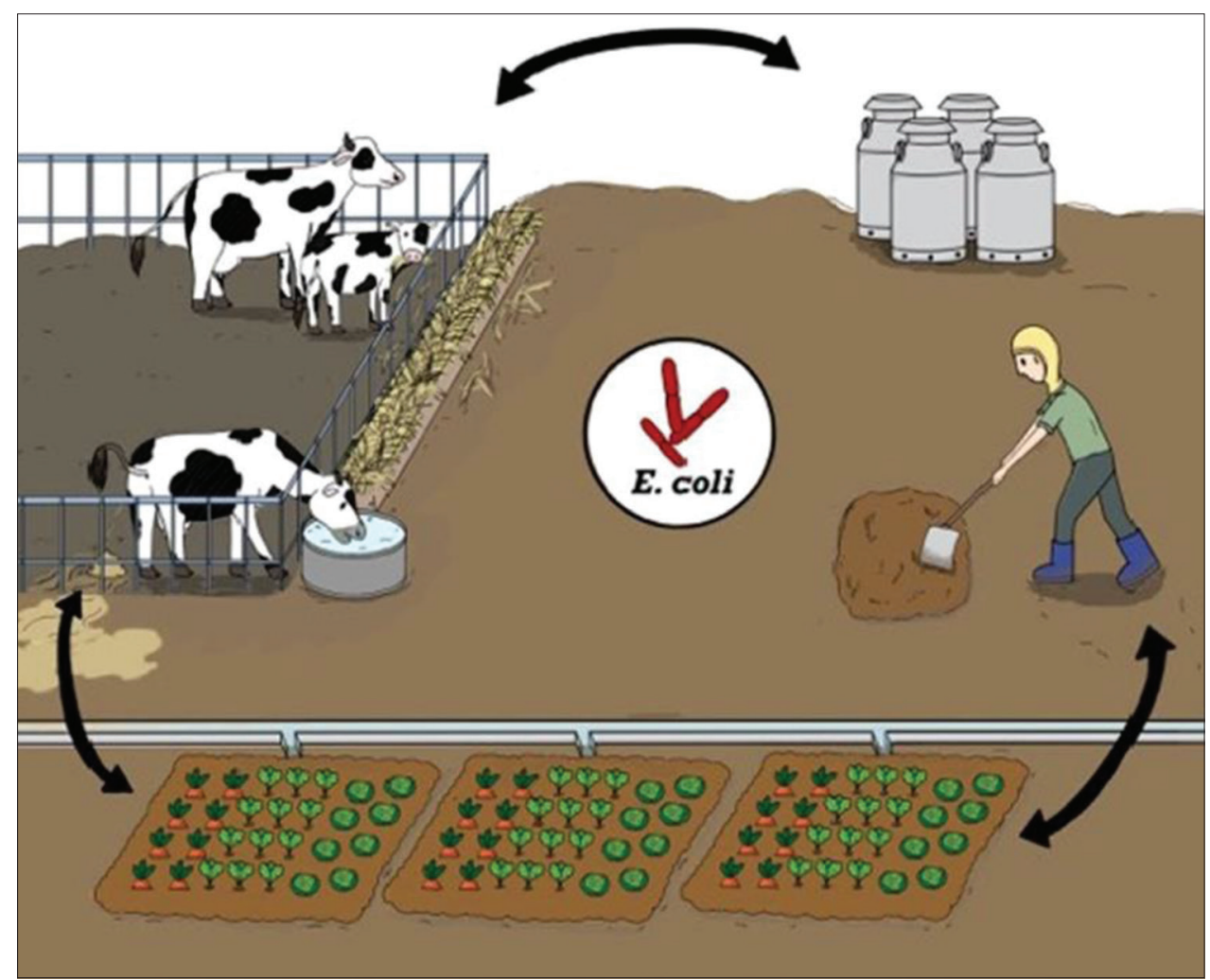

Figure-3: Circulation of carbapenem-resistant Escherichia coli between animals, environment, and humans in dairy farm (picture by Thamonphan Wimonsrinarachai).

\section{Conclusion}

This study afforded evidence that $E$. coli can be isolated from contaminated water sources at dairy farms in Maha Sarakham Province and Saraburi Province of Thailand. Furthermore, the detection of carbapenem-resistant $E$. coli from the water samples in dairy farms seems to be the first report of CRE isolated from an environmental source in Thailand. The findings should raise concerns regarding the improper usage of antimicrobial drugs in this area. Current practice might lead to more severe problems associated with antimicrobial resistance in the future. This information advocates that farmers or workers be concerned for clean environments such as water sources, soil, tools, and other fomites in the farms. They need to regularly change cow bedding at the milking areas and stalls, and regularly clean stall floors. Proper usage of antimicrobial drugs or use based on veterinary advice and improved mastitis control programs are required, and farm hygiene should be managed and advised by veterinarians. Finally, this study will be beneficial for further developing suitable One Health strategies to integrate the prevention and control of antimicrobial resistance in livestock farming.

\section{Authors' Contributions}

NP designed the study, collected the samples, done laboratory work. SP provided manuscript consultation and coordination. Both authors read and approved the final manuscript.

\section{Acknowledgments}

This research was funded by the Faculty of Veterinary Sciences, Mahasarakham University 2018 (grant no. 001/2561), Thailand. The authors are also gratefully to the Faculty of Veterinary Sciences, Mahasarakham University for allowing us to use the laboratory to carry out this experiment. The authors would like to thank Mr. Satitpong Promsatit, DVM, Saraburi Provincial Livestock Office, Department of Livestock Development, Ministry of Agriculture and Cooperatives, Saraburi, Thailand, for his cooperation in the field. Finally, the authors also thank Miss Thamonphan Wimonsrinarachai for the picture design.

\section{Competing Interest}

The authors declare that they have no competing interests.

\section{Publisher's Note}

Veterinary World (Publisher of International Journal of One Health) remains neutral with regard to jurisdictional claims in published map and institutional affiliation.

\section{References}

1. Friedman, N.D., Kaye, K.S., Stout, J.E., McGarry, S.A., Trivette, S.L., Briggs, J.P., Lamm, W., Clark, C., MacFarquhar, J., Walton, A.L., Reller, L.B. and Sexton, D.J. (2002) Health care associated bloodstream infections in adults: A reason to change the accepted definition of community-acquired infections. Ann. Intern. Med., 137(10): 791-797.

2. Jafari, A., Aslani, M.M. and Bouzari, S. (2012) Escherichia 
coli: A brief review of diarrheagenic pathotypes and their role in diarrheal diseases in Iran. Iran. J. Microbiol., 4(3): 102-117.

3. Burvenich, C., Merris, V.V., Mehrzad, J., Diez-Fraile, A. and Duchateau, L. (2003) Severity of E. coli mastitis is mainly determined by cow factors. Vet. Res., 34(5): 521-564.

4. Adzitey, F., Sumaila, N. and Saba, C.S. (2015) Isolation of $E$. Coli from drinking water sources for humans and farm animals in Nyankpala community of Ghana. Res. $J$. Microbiol., 10(3): 126-131.

5. Hinthong, W., Pumipuntu, N., Santajit, S., Kulpeanprasit, S., Buranasinsup, S., Sookrung, N., Chaicumpa, W., Aiumurai, P. and Indrawattana, N. (2017) Detection and drug resistance profile of Escherichia coli from subclinical mastitis cows and water supply in dairy farms in Saraburi province, Thailand. PeerJ, 5: e3431.

6. Adzitey, F., Nafisah, S., Haruna, A. (2015) Antibiotic susceptibility of Escherichia coli isolated from some drinking water sources in tamale metropolis of Ghana. Curr. Res. Bacteriol., 8(2): 34-40.

7. Yusha'u, M., Umar, M.I. and Suleiman, K. (2010) Indigenous commercial drinks as potential sources of extended-spectrum $\beta$-lactamases (ESBLS) producing organisms in Kano, Nigeria. Int. J. Biomed. Health Sci., 6(1): 103-108.

8. Mlynarcik, P., Roderova, M. and Kolar, M. (2016) Primer evaluation for PCR and its application for detection of carbapenemases in Enterobacteriaceae. Jundishapur J. Microbiol., 9(1): e29314.

9. World Health Organization. (2019) Antibiotic Resistance. World Health Organization, Geneva. Available from: http:// www.who.int/mediacentre/factsheets/antibiotic-resistance/ en. Accessed on 15-01-2019.

10. Fernandes, J.B., Zanardo, L.G., Galvão, N.N., Carvalho, I.A., Nero, L.A. and Moreira, M.A. (2011) Escherichia coli from clinical mastitis: Serotypes and virulence factors. J. Vet. Diagn. Invest., 23(6): 1146-1152.

11. Haftu, R., Taddele, H., Gugsa, G. and Kalayou, S. (2012) Prevalence, bacterial causes, and antimicrobial susceptibility profile of mastitis isolates from cows in large-scale dairy farms of Northern Ethiopia. Trop. Anim. Health Prod., 44(7): 1765-1771.

12. Abera, M., Habte, T., Aragaw, K., Asmare, K. and
Sheferaw, D. (2012) Major causes of mastitis and associated risk factors in smallholder dairy farms in and around Hawassa, Southern Ethiopia. Trop. Anim. Health Prod., 44(6): 1175-1179.

13. Olivares-Pérez, J., Kholif, A.E., Rojas-Hernández, S., Elghandour, M.M., Salem, A.Z., Bastida, A.Z., VelázquezReynoso, D., Cipriano-Salazar, M., Camacho-Díaz, L.M., Alonso-Fresán, M.U. and DiLorenzo, N. (2015) Prevalence of bovine subclinical mastitis, its etiology and diagnosis of antibiotic resistance of dairy farms in four municipalities of a tropical region of Mexico. Trop. Anim. Health Prod., 47(8): 1497-1504.

14. Wang, L., Yang, F., Wei, X., Luo, Y., Zhou, X., Guo, W., Niu, J. and Guo, Z. (2015) Investigation of bovine mastitis pathogen in two northwestern provinces of China from 2012-2014. J. Anim. Vet. Adv., 14(8): 237-243.

15. Momtaz, H., Dehkordi, F.S., Taktaz, T., Rezvani, A. and Yarali, S. (2012) Shiga toxin-producing Escherichia coli isolated from bovine mastitic milk: Serogroups, virulence factors, and antibiotic resistance properties. Sci. World J., 2012: 618709.

16. Ludden, C., Raven, K.E., Jamrozy, D., Gouliouris, T., Blane, B., Coll, F., de Goffau, M., Naydenova, P., Horner, C., Hernandez-Garcia, J., Wood, P., Hadjirin, N., Radakovic, M., Brown, N.M., Holmes, M., Parkhill, J. and Peacock, S.J. (2019) One health genomic surveillance of Escherichia coli demonstrates distinct lineages and mobile genetic elements in isolates from humans versus livestock. MBio, 10(1): e02693-18.

17. Fegan, N. and Gobius, K.S. (2013) Pathogenic Escherichia coli and one health implications. Curr. Top. Microbiol. Immunol., 366: 49-62.

18. García, A., Fox, J.G. and Besser, T.E. (2010) Zoonotic enterohemorrhagic Escherichia coli: A one health perspective. ILAR J., 51(3): 221-232.

19. Shrestha, K., Acharya, K.P. and Shrestha, S. (2018) One health: The interface between veterinary and human health. Int. J. One Health, 4: 8-14.

20. Sukumaran, A. and Pradeepkumar, A.S. (2015) One health approach: A platform for intervention in emerging public health challenges of Kerala state. Int. J. One Health, 1: 14-25. 